\title{
Nordamnacanthal potentiates the cytotoxic effects of tamoxifen in human breast cancer cells
}

\author{
TAMILSELVAN SUBRAMANI ${ }^{1}$, SWEE KEONG YEAP ${ }^{2}$, WAN YANG HO ${ }^{3}$, \\ CHAI LING HO ${ }^{1}$, CHE PUTEH OSMAN ${ }^{4}$, NOR HADIANI ISMAIL ${ }^{4}$, \\ NIK MOHD AFIZAN NIK ABDUL RAHMAN ${ }^{1}$ and NOORJAHAN BANU ALITHEEN ${ }^{1}$
}

${ }^{1}$ Department of Cell and Molecular Biology, Faculty of Biotechnology and Biomolecular Sciences; ${ }^{2}$ Institute of Bioscience, Universiti Putra Malaysia, Serdang, Selangor 43400; ${ }^{3}$ Faculty of Medicine and Health Science, School of

Biomedical Sciences, The University of Nottingham Malaysia Campus, Semenyih, Selangor 43500;

${ }^{4}$ Faculty of Applied Sciences, Universiti Teknologi Mara, Shah Alam, Selangor 40450, Malaysia

Received September 29, 2013; Accepted April 10, 2014

DOI: $10.3892 / \mathrm{ol} .2014 .2697$

\begin{abstract}
Tamoxifen (TAM) is the mainline drug treatment for breast cancer, despite its side effects and the development of resistance. As an alternative approach, in the present study a novel combination therapy was established through combining TAM with nordamnacanthal (NDAM) in order to investigate the additive effect of these drugs in MCF-7 human breast cancer cells. A significant dose-dependent reduction in cell viability and an increase in apoptosis were observed in the MCF-7 cells cotreated with TAM and NDAM compared with the untreated control cells or the cells treated with TAM and NDAM alone $(\mathrm{P}<0.05)$. The cytotoxic influence of the combination of TAM and NDAM was found to be two-fold that of the individual agents. Annexin V/propidium iodide double-staining revealed the typical nuclear features of apoptosis. Furthermore, an increase in the proportion of apoptotic, Annexin V-positive cells was observed with the combination therapy. Moreover, this apoptotic induction was associated with a collapse of the mitochondrial membrane potential and the generation of reactive oxygen species. To the best of our knowledge, the findings of the present study are the first to suggest that combining TAM with NDAM may be a potential combination therapy for the treatment of breast cancer and may have the potential to minimize or eliminate the side effects associated with high doses of TAM.
\end{abstract}

Correspondence to: Dr Noorjahan Banu Alitheen, Department of Cell and Molecular Biology, Faculty of Biotechnology and Biomolecular Sciences, Universiti Putra Malaysia, Serdang, Selangor 43400, Malaysia

E-mail: noorjahan@biotech.upm.edu.my

Key words: tamoxifen, nordamnacanthal, MCF-7, breast cancer, combination treatment, apoptosis

\section{Introduction}

Breast cancer is the most common type of cancer in the female population (1). Despite significant progress in the treatment of breast cancer over the past decades, breast cancer remains the primary cause of cancer-related mortality in females worldwide $(1,2)$. The development and progression of this chronic disease involves the deregulation and activation of multiple signaling pathways at various stages in carcinogenesis. This complexity associated with breast cancer causes limitations in designing high-efficacy therapeutic strategies. Tamoxifen (TAM) is the mainline drug prescribed for patients with metastatic breast cancer (3). TAM has been reported to reduce the risk of recurrence and mortality in patients with breast cancer when administered as an adjuvant therapy (4). TAM is a non-steroidal selective estrogen receptor modulator, which is particularly effective in post-menopausal women who have a significant risk of developing estrogen receptor-positive breast cancer $(5,6)$. The antitumor activity of TAM has been proposed to be cytostatic and cytotoxic for breast cancer. More specifically, TAM has been shown to interact with the mitochondrial estrogen receptor and increase the reactive oxygen species concentrations from the mitochondria required for the cytotoxicity $(7,8)$. However, there are serious side effects associated with the prolonged use of high-dose TAM, particularly in the uterus, which manifests as abnormal proliferation and an increase in the risk of endometrial cancer (9-12). Therefore, novel therapeutic approaches that could increase TAM sensitivity are required, so that lower doses may be used without compromising TAM efficacy. One potential strategy may be the combination of TAM with other agents that increase the efficacy and decrease the toxicity of TAM. Nordamnacanthal (NDAM), also known as 2-formyl-1,3-dihydroxyanthraquinone, is an anthraquinone extracted from the roots of Morinda elliptica (13). NDAM has been reported to have a number of biological properties, including antitumor effects $(14,15)$. A previous study has shown that depending upon the concentration/dose, NDAM is capable of triggering and blocking cell death signaling in tumor cells (16). Since both TAM and NDAM have antitumor properties, a combination of these 
drugs may be a therapeutic option for patients with breast cancer. However, their potential additive effects have yet to be elucidated. Therefore, the present study aimed to investigate the effect of TAM and NDAM on apoptosis, cell cycle arrest, mitochondrial membrane potential $\left(\Delta \psi_{\mathrm{m}}\right)$ and oxidative stress in MCF-7 human breast cancer cells.

\section{Materials and methods}

Cells and cell culture. The estrogen-sensitive MCF-7 human breast cancer cell line was obtained from the American Type Culture Collection (Rockville, MD, USA). Cells were cultured as monolayers in RPMI-1640 (Sigma-Aldrich, , St. Louis, MO, USA) medium supplemented with $10 \%$ heat-inactivated fetal bovine serum (Gibco-BRL, Carlsbad, CA, USA), $100 \mathrm{U} / \mathrm{ml}$ penicillin and $100 \mu \mathrm{g} / \mathrm{ml}$ streptomycin (both Sigma-Aldrich) at $37^{\circ} \mathrm{C}$ in a humidified environment containing $5 \% \mathrm{CO}_{2}$.

Drugs and drug treatment. NDAM was isolated from the roots of M. elliptica using solvent fractionation and was purified using high-performance liquid chromatography techniques. The structure was identified by comparing spectroscopic data as reported in our previous study (13). NDAM was dissolved in dimethyl sulfoxide (DMSO; Sigma-Aldrich) and stored at $-20^{\circ} \mathrm{C}$ as a $10-\mathrm{mg} / \mathrm{ml}$ stock solution. TAM (Sigma-Aldrich) was dissolved in DMSO at a concentration of $10 \mathrm{mg} / \mathrm{ml}$. In the control experiments, equal quantities of DMSO were added. The structure of TAM and NDAM are shown in Fig. 1.

Cytotoxicity assay. Cells were seeded at a density of 5000 cells/well in 96-well microtiter culture plates and incubated overnight. The culture medium was replaced with fresh medium containing various concentrations of NDAM $(0-30 \mu \mathrm{g} / \mathrm{ml})$ and TAM $(0-30 \mu \mathrm{g} / \mathrm{ml})$ alone or in combination for 24,48 and $72 \mathrm{~h}$. A total of $20 \mu \mathrm{l} 3-(4$, 5-dimethylthaiazol-2-yl)-2-5-diphenyltetrazolium bromide (MTT; Calbiochem, Darmstadt, Germany) solution $(0.5 \mathrm{mg} / \mathrm{ml})$ was added to each well and cell proliferation was analyzed as described previously (14).

Cell viability assay. Cell death was quantified in the MCF-7 cells using propidium iodide (PI; Sigma-Aldrich) and acridine orange (AO; Sigma-Aldrich) double-staining as described previously, using a fluorescence microscope (Diaphot, Nikon Inc., Melville, NY, USA) (14). The MCF-7 cells were seeded in a $25-\mathrm{ml}$ culture flask at a concentration of $1 \times 10^{6}$ cells $/ \mathrm{ml}$ and treated with NDAM and TAM alone or in combination and were incubated at $37^{\circ} \mathrm{C}$ with $5 \% \mathrm{CO}_{2}$ for $72 \mathrm{~h}$. The cells were washed with phosphate-buffered saline (PBS) and stained with $10 \mu \mathrm{l} \mathrm{AO}(10 \mu \mathrm{g} / \mathrm{ml})$ and PI $(10 \mu \mathrm{g} / \mathrm{ml})$. Slides were analyzed under UV-fluorescence microscopy (Nikon Inc.) and the number of viable, apoptotic and necrotic cells was calculated.

Annexin $V$ binding assay. MCF-7 cells were treated with NDAM and TAM alone or in combination for $72 \mathrm{~h}$. Cells were resuspended in Annexin V binding buffer (BD Pharmingen, San Diego, CA, USA) to a concentration of $1 \times 10^{6}$ cells $/ \mathrm{ml}$. Annexin V-fluorescein isothiocyanate (FITC; BD Biosciences, San Diego, CA, USA) was incubated for $15 \mathrm{~min}$ in the dark
A<smiles>CCC(=C(c1ccccc1)c1ccccc1)c1ccc(OCCN(C)C)cc1</smiles>

B<smiles>O=Cc1c(O)cc2c(c1O)C(=O)c1ccccc1C2=O</smiles>

Figure 1. Chemical structure of (A) tamoxifen and (B) nordamnacanthal.

in $100 \mu 1$ cell suspension. PI was then spiked into $400 \mu \mathrm{l}$ Annexin $\mathrm{V}$ binding buffer and added immediately to the cell suspension, and subsequently analyzed using a FACSCaliber ${ }^{\mathrm{TM}}$ system with CellQuest ${ }^{\mathrm{TM}}$ software (both BD Biosciences). Care was taken to collect trypsinized cells and cells which may have been floating prior to trypsinization to ensure that apoptotic cells, if present, were detected.

Cell cycle analysis. MCF-7 cells $(5,000$ cells $/ \mathrm{ml})$ were seeded onto $25 \mathrm{~cm}^{2}$ flasks with NDAM and TAM either alone or combined for $72 \mathrm{~h}$. The cells were trypsinized and washed with PBS then centrifuged at 2,000 x g for $5 \mathrm{~min}$. The cell pellet was resuspended in $1 \mathrm{ml} 0.1 \%$ sodium citrate containing $0.05 \mathrm{mg}$ PI and $50 \mu \mathrm{g}$ RNase (Sigma-Aldrich) for $30 \mathrm{~min}$ at room temperature in the dark. Flow cytometric analysis was performed using a FACScan system (BD Biosciences) and CellQuest software.

Assessment of $\Delta \psi_{m}$. MCF-7 cells $\left(1 \times 10^{6}\right)$ were grown in $25-\mathrm{ml}$ culture flasks for $24 \mathrm{~h}$, followed by incubation with NDAM and TAM alone or in combination in culture medium for $72 \mathrm{~h}$ at $37^{\circ} \mathrm{C}$. The $\Delta \psi_{\mathrm{m}}$ was assessed using a $\mathrm{BD}^{\mathrm{TM}}$ MitoScreen kit (BD Biosciences) according to the manufacturer's instructions, and analyzed using a FACSCaliber system (BD Biosciences). The ratio of $\Delta \psi_{\mathrm{m}} /$ mitochondrial mass was calculated to correct the $\Delta \psi_{\mathrm{m}}$ for differences in mitochondrial mass.

Assessment of lipid peroxidation. Lipid peroxidation was assessed through analyzing the lipid peroxidation marker malondialdehyde in the cell lysates $(17,18)$. Cells were treated with NDAM and TAM alone or in combination at $37^{\circ} \mathrm{C}$ with $5 \% \mathrm{CO}_{2}$ for $72 \mathrm{~h}$. The treated MCF-7 cells were washed in ice-cold PBS and lysed in $260 \mu 1$ solubilization buffer [10 mM Tris (pH 7.4), $9 \mathrm{~g} / 1 \mathrm{NP} 40,1 \mathrm{~g} / 1 \mathrm{SDS}$ and $250 \mathrm{U} / \mathrm{ml}$ benzonase; Sigma-Aldrich). Approximately $200 \mu 1$ cell lysate or malondialdehyde standards (Sigma-Aldrich) were mixed with $10 \mu \mathrm{l}$ butylated hydroxytoluene $(50 \mathrm{mg} / \mathrm{ml}$ ethanol) and $200 \mu \mathrm{l}$ orthophosphoric acid $(0.2 \mathrm{mM})$. The reaction mixture was incubated on ice for $30 \mathrm{~min}$ and centrifuged at $2000 \mathrm{x} \mathrm{g}$ for 
A

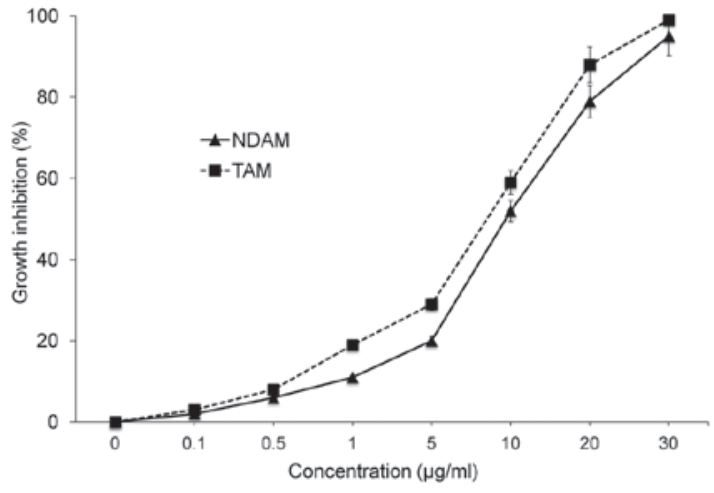

B

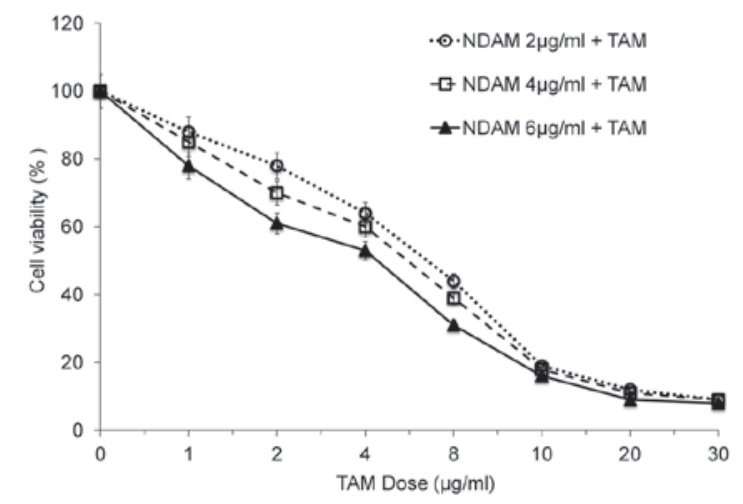

C

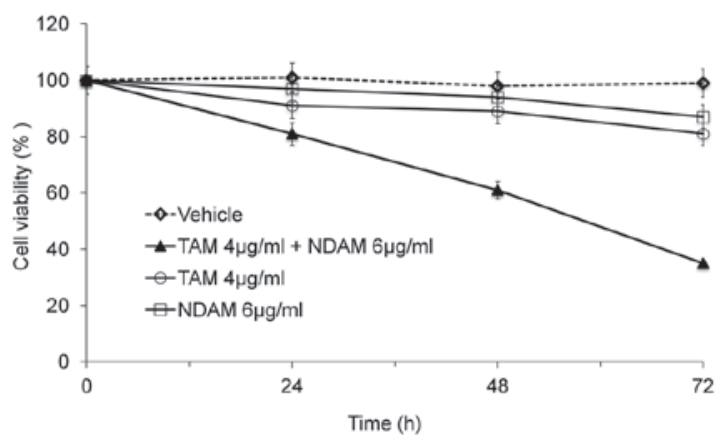

Figure 2. MCF-7 proliferation following treatment with TAM and NDAM alone or combined. Cells growing in the log-phase were trypsinized and plated onto 96-well plates at a density of 5,000 cells/well. Following incubation for $24 \mathrm{~h}$, cells were treated with various concentrations of TAM and NDAM either (A) alone or (B) combined. (C) After 24,48 and $72 \mathrm{~h}$ of treatment, cell proliferation was assessed using 3-(4,5-dimethylthaiazol-2-yl)-2-5-diphenyltetrazolium bromide assay. Data are presented as the mean \pm standard deviation of three independent experiments. TAM, tamoxifen; NDAM, nordamnacanthal.

$15 \mathrm{~min}$ at $25^{\circ} \mathrm{C}$. The supernatant was separated and added to $25 \mu \mathrm{l}$ 2-thiobarbituric acid reagent $(800 \mathrm{mg}$ 2-thiobarbituric acid dissolved in $50 \mathrm{ml} 0.1 \mathrm{M} \mathrm{NaOH}$ ) and incubated at $90^{\circ} \mathrm{C}$ for $45 \mathrm{~min}$. Formed malondialdehyde equivalents, thiobarbituric acid-reactive substances (TBARS), were extracted and measured using a plate reader (Bio-Rad Laboratories, Inc.) with excitation at $532 \mathrm{~nm}$ and $600 \mathrm{~nm}$. Malondialdehyde standard solution was used for qualitative determination of TBARS. The Bradford assay was performed in order to measure the protein content.

Statistical analysis. All experiments were performed in triplicate. The statistical significance of the differences was

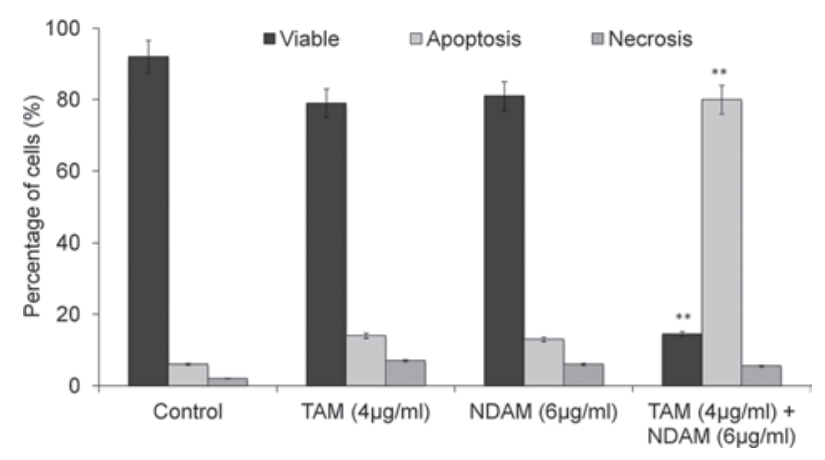

Figure 3. Morphological assessment of MCF-7 cells stained with acridine orange and propidium iodine following treatment with TAM and NDAM alone or combined. Cells were incubated with TAM $(4 \mu \mathrm{g} / \mathrm{ml})$ or NDAM $(6 \mu \mathrm{g} / \mathrm{ml})$ or a combination of TAM and NDAM for $72 \mathrm{~h}$. Data are presented as the mean \pm standard deviation of three independent experiments. ${ }^{* *} \mathrm{P}<0.05$ vs. control. TAM, tamoxifen; NDAM, nordamnacanthal.

determined using one-way analysis of variance followed by Dunnett's multiple comparison test. Values are presented as the mean \pm standard deviation and $\mathrm{P}<0.05$ was considered to indicate a statistically significant difference.

\section{Results}

NDAM enhances the cytotoxic effect of TAM. In the present study, it was hypothesized that TAM in combination with NDAM may be a superior therapeutic strategy for breast cancer. In order to test this hypothesis, the effect of incremental doses of TAM and NDAM, alone or combined, was analyzed on the growth of MCF-7 human breast cancer cells. Cellular growth, determined using MTT assay, revealed that TAM and/or NDAM were effective in inhibiting the growth of the MCF-7 cells in a dose-dependent manner (Fig. 2A). Low doses of TAM $(4 \mu \mathrm{g} / \mathrm{ml})$ were observed to reduce the proliferation of breast cancer cells and complete cell death was achieved at a concentration of $23 \mu \mathrm{g} / \mathrm{ml}$ following treatment for $72 \mathrm{~h}$ (Fig. 2B). At a concentration of $6 \mu \mathrm{g} / \mathrm{ml}$, NDAM was found to reduce cell viability by $24.5 \%$ and complete cell death was achieved at a concentration of $28 \mu \mathrm{g} / \mathrm{ml}$ NDAM (Fig. 2B). Upon combining NDAM with TAM, a markedly enhanced induction of cell death was observed, even at lower TAM concentrations (Fig. 2B). While treatment with $4 \mu \mathrm{g} / \mathrm{ml}$ TAM alone did not significantly reduce MCF-7 cell viability (12\%), the combination of NDAM $(6 \mu \mathrm{g} / \mathrm{ml})$ and TAM $(4 \mu \mathrm{g} / \mathrm{ml})$ was found to significantly reduce $\mathrm{MCF}-7$ cell viability by up to $77.0 \%$ (Fig. $2 \mathrm{C} ; \mathrm{P}<0.05$ ). The same concentrations of TAM and NDAM were not sufficient to induce apoptosis when used alone.

NDAM enhances TAM-induced apoptosis. Morphological changes were observed in the cells treated with the TAM/NDAM combination. Co-incubation of MCF-7 cells with TAM and NDAM resulted in significantly increased levels of apoptosis (Fig. 3) compared with the control cells and those treated with TAM or NDAM alone, with the proportion of the viable cells accounting for only $14.5 \%$ of the total cell population and $79 \%$ undergoing apoptosis. Necrotic cells were also observed in the treatment group, but the numbers were insignificant. Treatment with NDAM $(6 \mu \mathrm{g} / \mathrm{ml})$ and TAM $(4 \mu \mathrm{g} / \mathrm{ml})$ alone 

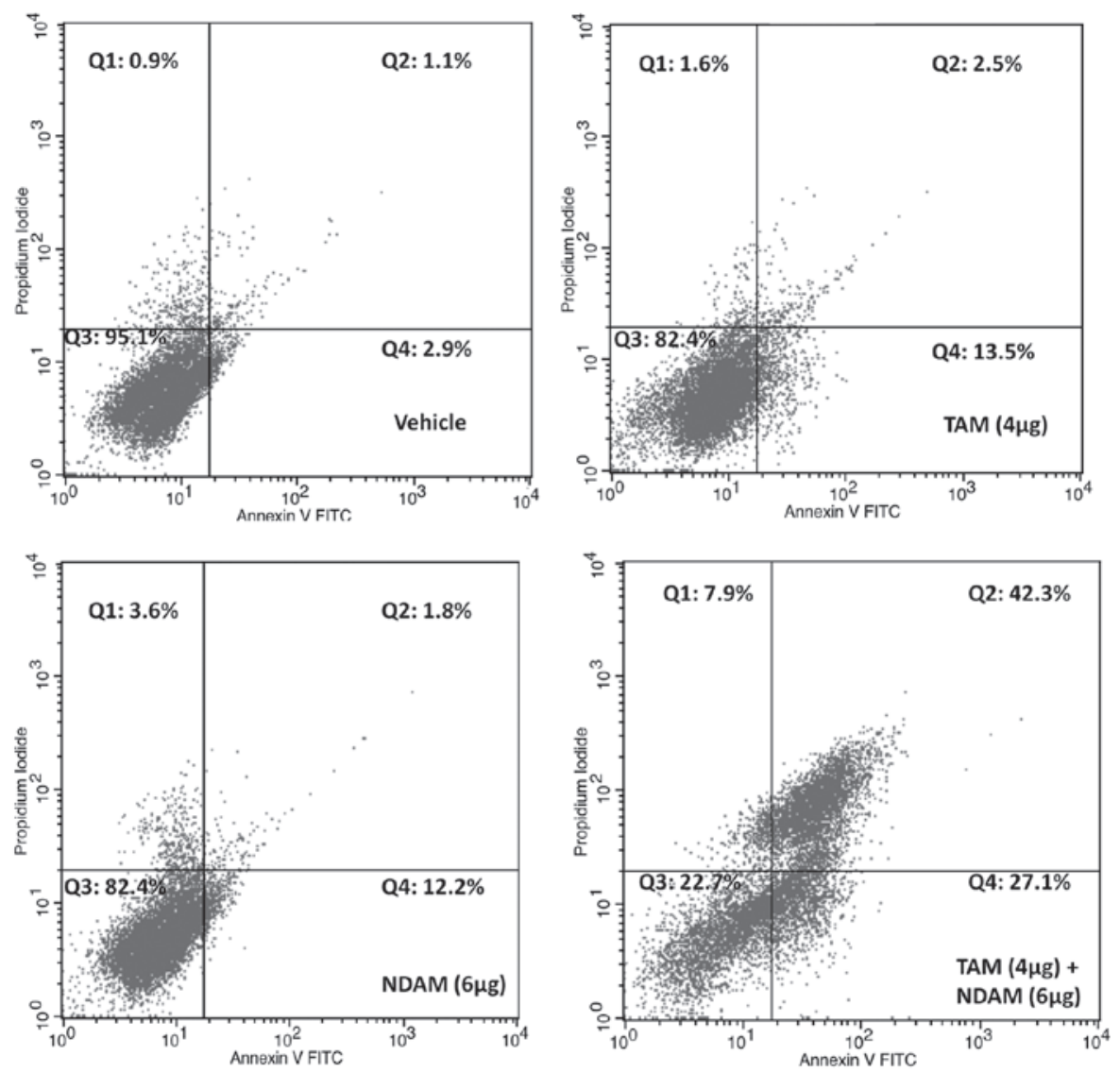

Figure 4. Flow cytometric analysis of MCF-7 cells treated with TAM $(4 \mu \mathrm{g} / \mathrm{ml})$ and NDAM $(6 \mu \mathrm{g} / \mathrm{ml})$ alone or in combination for $72 \mathrm{~h}$ and stained with Annexin V-FITC/propidium iodide. Graphs are representative of 10,000 cells from a single replicate. TAM, tamoxifen; NDAM, nordamnacanthal; FITC, Fluorescein isothiocyanate.

was not found to induce significant levels of apoptosis in the MCF-7 cells (Fig. 4). Annexin V-FITC analysis was performed to confirm the induction of apoptosis in the MCF-7 cells upon cotreatment with TAM and NDAM. Fluorescence-activated cell sorting revealed a significant increase in apoptotic cells (69\%) upon cotreatment with TAM and NDAM for $72 \mathrm{~h}$ compared with the vehicle-treated cells (4\%) or those treated with TAM (16\%) or NDAM (14\%) alone (Fig. 4). Cell cycle analysis revealed an increase in $\mathrm{G}_{0} / \mathrm{G}_{1}$-phase accumulation in the TAM/NDAM-treated cells $(63 \% ; \mathrm{P}<0.01)$ compared with the DMSO-treated cells (45\%), with a concomitant decrease in the percentage of cells in the $\mathrm{G}_{2} / \mathrm{M}$ phase observed in the TAM/NDAM-treated cells (Fig. 5). Cell cycle arrest occurred from $24 \mathrm{~h}$ of treatment (data not shown) and longer treatment durations showed that TAM/NDAM induced $\mathrm{G}_{0} / \mathrm{G}_{1}$ arrest and apoptosis in the treated cells. However, no significant increases in cell cycle arrest were observed in the MCF-7 cells treated with NDAM $(6 \mu \mathrm{g} / \mathrm{ml})$ and TAM $(4 \mu \mathrm{g} / \mathrm{ml})$ alone.

NDAM enhances the TAM-induced changes in $\Delta \psi_{m}$ and lipid peroxidation. Changes in $\Delta \psi_{\mathrm{m}}$ are considered to be an indicator of mitochondrial damage. It has also been reported that high quantities of reactive oxygen intermediates result in lipid peroxidation (18). Therefore, the present study analyzed the $\Delta \psi_{\mathrm{m}}$ and the lipid peroxidation end product malondialdehyde in MCF-7 cells treated with TAM and NDAM, alone or combined. As shown in Fig. 6, changes in the $\Delta \psi_{\mathrm{m}}$ were

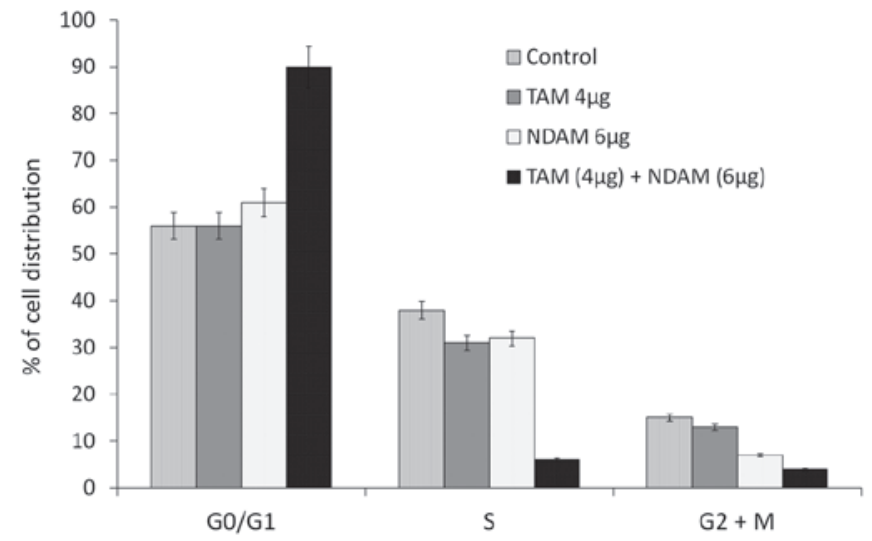

Figure 5. Cell cycle analysis detected using flow cytometry. MCF-7 cells treated with TAM $(4 \mu \mathrm{g} / \mathrm{ml})$ and NDAM $(6 \mu \mathrm{g} / \mathrm{ml})$ either alone and in combination for $72 \mathrm{~h}$ were stained with propidium iodide. The control cells were treated with dimethyl sulfoxide. Results are representative of three independent experiments. Data are presented as the mean \pm standard deviation $(n=4)$ of the percentage of cells in individual phases of the cell cycle from four independent experiments. TAM, tamoxifen; NDAM, nordamnacanthal.

observed in the in MCF-7 cells following TAM/NDAM exposure for $72 \mathrm{~h}$. By contrast, administration of NDAM $(6 \mu \mathrm{g} / \mathrm{ml})$ or TAM $(4 \mu \mathrm{g} / \mathrm{ml})$ alone had no significant effect on the $\Delta \psi_{\mathrm{m}}$. The $\Delta \psi_{\mathrm{m}}$ in the DMSO-treated cells was unchanged throughout all of the incubation time-periods. Furthermore, TAM/NDAM cotreatment was observed to have an effect on 


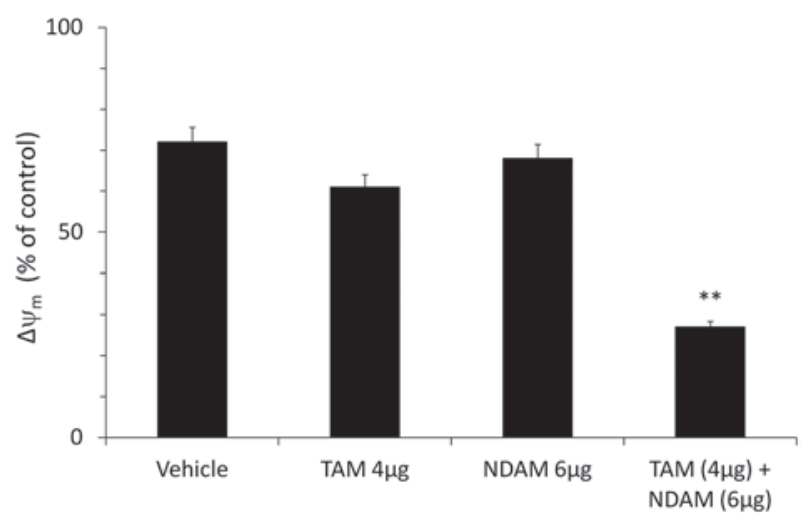

Figure 6. MCF-7 cells exposed to TAM $(4 \mu \mathrm{g} / \mathrm{ml})$ and NDAM $(6 \mu \mathrm{g} / \mathrm{ml})$ alone or in combination for $72 \mathrm{~h}$. The $\Delta \psi_{\mathrm{m}}$ was determined using flow cytometry. The $\Delta \psi_{\mathrm{m}}$ of the MCF-7 cells treated with TAM/NDAM decreased significantly compared with that of the control cells and those treated with TAM or NDAM alone. $\Delta \psi_{\mathrm{m}}$ levels, expressed as mean fluorescence intensity, were calculated as a percentage of the control. Data are presented as the mean \pm standard deviation of at least triplicate experiments. ${ }^{* *} \mathrm{P}<0.05$ vs. control. TAM, tamoxifen; NDAM, nordamnacanthal; $\Delta \psi \mathrm{m}$, mitochondrial membrane potential.

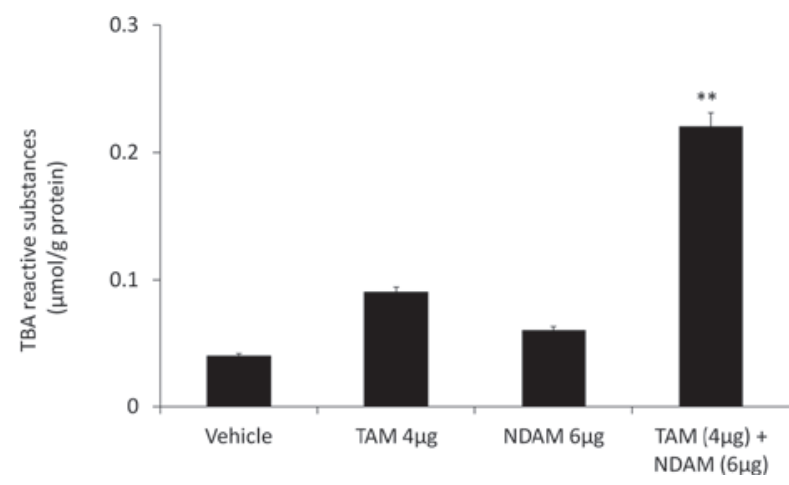

Figure 7. TBA reactive substances release from MCF-7 cells exposed to TAM $(4 \mu \mathrm{g} / \mathrm{ml})$ and NDAM $(6 \mu \mathrm{g} / \mathrm{ml})$ either alone or in combination for $72 \mathrm{~h}$. Lipid peroxidation was analyzed through measuring the malonaldehyde equivalents TBA reactive substances. A significant increase in TBA reactive substances was observed in the MCF-7 cells following treatment with TAM/NDAM compared with that of treatment with TAM or NDAM alone Data are presented as the mean \pm standard deviation of at least three independent experiments. ${ }^{* *} \mathrm{P}<0.05$ vs. control. TBA, thiobarbituric acid; TAM, tamoxifen; NDAM, nordamnacanthal.

lipid peroxidation, as demonstrated by the significant release of the malondialdehyde equivalent TBARS from treated MCF-7 cells (Fig. 7). However, treatment with NDAM $(6 \mu \mathrm{g} / \mathrm{ml})$ and TAM $(4 \mu \mathrm{g} / \mathrm{ml})$ alone were not found to induce significant TBARS release in the MCF-7 cells.

\section{Discussion}

TAM has been used for more than two decades for hormone therapy in breast carcinomas expressing the estrogen receptor. Although TAM is well tolerated and has resulted in a 5-15\% absolute reduction in recurrence and mortality (4), more effective treatments for estrogen receptor-positive breast cancer are required. In addition to the side effects associated with TAM, it has been estimated that $90 \%$ of patients with breast cancer acquire resistance to TAM within one year (19). Support has increased for the use of natural compounds that enhance the therapeutic effect of antineoplastic agents so that lower doses may be used to achieve the same antineoplastic effect, while simultaneously avoiding or minimizing the side effects associated with high doses. In the present study, the results showed that the cytotoxic effect of TAM on breast cancer cells was enhanced through combined treatment with NDAM, thus allowing the effective concentration of TAM to be reduced. The growth inhibition advantage of combining NDAM with TAM was primarily due to enhanced cell cycle arrest and apoptosis. The cytotoxic effect was assessed through combining NDAM $(6 \mu \mathrm{g} / \mathrm{ml})$ at a concentration which did not enhance apoptosis, with the chemotherapeutic agent TAM $(4 \mu \mathrm{g} / \mathrm{ml})$. When NDAM was combined with a subapoptotic dose of the chemotherapeutic agent, significant apoptosis was induced. The primary growth inhibitory mechanism for TAM in MCF-7 cells has been reported to be cell cycle inhibition $(20,21)$. In the present study, TAM/NDAM treatment was found to induce significant $\mathrm{G}_{0} / \mathrm{G}_{1}$-phase arrest in the MCF-7 cells. By contrast, treatment with TAM or NDAM did not induce a significantly greater $\mathrm{G}_{0} / \mathrm{G}_{1}$-phase arrests in the MCF-7 cells compared with TAM/NDAM cotreatment. Previous studies have shown that TAM induces significant $\mathrm{G}_{0} / \mathrm{G}_{1}$-phase arrest in breast cancer cells $(20,22)$. Furthermore, in agreement with the present study, Li et al (23) showed that combined treatment of TAM with organoselenium compounds enhanced apoptosis. These results show that TAM/NDAM-induced cell growth inhibition is concomitant with major changes in the cell cycle in MCF-7 cells.

In mammalian cells, the mitochondria have a fundamental role in apoptosis. At the early stage of apoptosis, mitochondrial damage occurs through disruption of the $\Delta \psi_{\mathrm{m}}$ which leads to the activation of caspase cascades (24). In the present study, the combination of TAM/NDAM was observed to induce a significant loss of $\Delta \psi_{\mathrm{m}}$ in the MCF-7 breast cancer cells. However, when low doses of TAM and NDAM were applied individually, neither of the drugs caused damage to the mitochondrial membrane. Furthermore, in the present study, an increase in TBARS release was observed following TAM/NDAM treatment for $72 \mathrm{~h}$, while no significant TBARS release was found following treatment with TAM or NDAM alone. These findings suggest that TAM/NDAM-induced TBARS release from MCF-7 cells may have caused the loss of $\Delta \psi_{\mathrm{m}}$. In conclusion, in the present study, NDAM was found to enhance the cytotoxic activity of TAM, with the inhibition of cell proliferation, $\mathrm{G}_{0} / \mathrm{G}_{1}$-phase arrest, the generation of oxidative damage and the loss of $\Delta \psi_{\mathrm{m}}$ cumulating in apoptosis following TAM/NDAM cotreatment. Combining NDAM with TAM was found to reduce the dose of TAM required to achieve the same therapeutic effect; therefore, this combination therapy has the potential to be a treatment regimen for breast cancer with minimal or no side effects that are frequently associated with high doses of TAM. However, it is important to investigate the safety and tolerability of TAM/NDAM in vivo.

\section{References}

1. Jemal A, Siegel R, Ward E, et al: Cancer statistics, 2009. CA Cancer J Clin 59: 225-249, 2009.

2. Goldhirsch A, Ingle JN, Gelber RD, et al: Thresholds for therapies: highlights of the St Gallen International Expert Consensus on the primary therapy of early breast cancer 2009. Ann Oncol 20: 1319-1329, 2009. 
3. Radmacher MD and Simon R: Estimation of tamoxifen's efficacy for preventing the formation and growth of breast tumors. J Natl Cancer Inst 92: 48-53, 2000.

4. Early Breast Cancers Trialists' collaborative group: Tamoxifen for an early breast cancer: an overview of the randomised trials. Lancet 351: 1451-1467, 1998.

5. Love RR: Tamoxifen therapy in primary breast cancer: biology, efficacy, and side effects. J Clin Oncol 7: 803-815, 1989.

6. Marshall E: Tamoxifen: 'a big deal,' but a complex hand to play. Science 280: 196, 1998.

7. Parvez S, Tabassum H, Rehman $\mathrm{H}$, et al: Catechin prevents tamoxifen-induced oxidative stress and biochemical perturbations in mice. Toxicology 225: 109-118, 2006.

8. Conklin KA: Chemotherapy-associated oxidative stress: impact on chemotherapeutic effectiveness. Integr Cancer Ther 3: 294-300, 2004

9. Fisher B, Constantino JP, Wickerham CD, et al: Tamoxifen for prevention of breast cancer: report of the National Surgical Adjuvant Breast and Bowel Project P-1 Study. J Natl Cancer Inst 90: 1371-1388, 1998.

10. Fornander T, Rutqvist LE, Cedermark B, et al: Adjuvant tamoxifen in early breast cancer: occurrence of new primary cancers. Lancet 1: 117-120, 1989.

11. Johnston SR, Dowsett M and Smith IE: Towards a molecular basis for tamoxifen resistance in breast cancer. Ann Oncol 3 : 503-511, 1992

12. Osborne CK: Tamoxifen in the treatment of breast cancer N Engl J Med 339: 1609-1618, 1998

13. Ismail NH, Ali AM, Aimi N, et al: Anthraquinones from Morinda elliptica. Phytochemistry 45: 1723-1725, 1997.

14. Yazan LS, Ishak N and Lajis NH: BCL-2 was downregulated in G2/M-arrest breast cancer cells MCF-7-treated with Nordamnacanthal. J Pharm Sci \& Res 2: 197-207, 2010.

15. Jasril, Lajis NH, Mooi LY, Abdullah MA, Sukari MA and Ali AM: Antitumor promoting and antioxidant activities of anthraquinones isolated from cell suspension culture of Morinda elliptica. Asia Pac J Mol Biol. Biotechnol 11: 3-7, 2003
16. Kamiya K, Hamabe W, Tokuyama S, et al: Inhibitory effect of anthraquinones isolated from the noni (Morinda citrifolia) root on animal A-, B-, and Y-families of DNA polymerases and human cancer cell proliferation. Food Chem 118: 725-730, 2009.

17. Frank J, Kelleher DK, Pompella A, et al: Enhancement of oxidative cell injury and antitumor effects of localized 44 degrees $C$ hyperthermia upon combination with respiratory hyperoxia and xanthine oxidase. Cancer Res 58: 2693-2698, 1998.

18. Jentzsch AM, Bachmann H, Furst $\mathrm{P}$ and Biesalski HK: Improved analysis of malondialdehyde in human body fluids. Free Radic Biol Med 20: 251-256, 1996.

19. Johnston SR: Acquired tamoxifen resistance in human breast cancer - potential mechanisms and clinical implications. Anticancer Drugs 8: 911-930, 1997.

20. Danova M, Pellicciari C, Zibera C, et al: Cell cycle kinetic effects of tamoxifen on human breast cancer cells. Flow cytometric analyses of DNA content, BrdU labeling, Ki-67, PCNA, and statin expression. Ann NY Acad Sci 698: 174-181, 1993.

21. Osborne CK, Boldt DH, Clark GM and Trent JM: Effects of tamoxifen on human breast cancer cell cycle kinetics: accumulation of cells in early G1 phase. Cancer Res 43: 3583-3585, 1983.

22. Li S, Zhou Y, Wang R, et al: Selenium sensitizes MCF-7 breast cancer cells to doxorubicin-induced apoptosis through modulation of phospho-Akt and its downstream substrates. Mol Cancer Ther 6: 1031-1038, 2007.

23. Li Z, Carrier L and Rowan BG: Methylseleninic acid synergizes with tamoxifen to induce caspase-mediated apoptosis in breast cancer cells. Mol Cancer Ther 7: 3056-3063, 2008.

24. Green DR and Reed JC: Mitochondria and apoptosis. Science 281: 1309-1312, 1998 . 